\title{
New evidence of the evolutionary relationship of the flavida complex with the genus Panstrongylus (Hemiptera, Triatominae) by karyosystematic
}

\author{
K. C. Borsatto ${ }^{a}$, Y. V. Reis ${ }^{a}$, F. F. F. Moreira ${ }^{b}$, M. T. V. Azeredo-Oliveira ${ }^{a}$ and K. C. C. Alevia* \\ ${ }^{a}$ Laboratório de Biologia Celular, Departamento de Biologia, Instituto de Biociências, Letras e Ciências Exatas - IBILCE, \\ Universidade Estadual Paulista "Júlio de Mesquita Filho" - UNESP, Rua Cristóvão Colombo, 2265, Jardim Nazareth, \\ CEP 15054-000, São José do Rio Preto, SP, Brazil

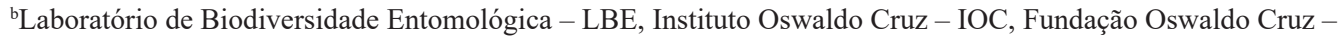 \\ FIOCRUZ, Av. Brasil 4365, Pavilhão Mourisco, $2^{\circ}$ andar, Manguinhos, CEP 21040-360, Rio de Janeiro, RJ, Brazil \\ *e-mail: kaiochaboli@hotmail.com
}

Received: March 1, 2017 - Accepted: April 26, 2017 - Distributed: November 30, 2018

\section{Scientific note}

The Triatominae subfamily (Hemiptera, Reduviidae) is composed of 152 species belonging to 18 genera and five tribes (Galvão, 2014; Alevi et al., 2016; Mendonça et al., 2016; Souza et al., 2016; Rosa et al., 2017). The Triatomini tribe is the most diverse and one of the most important from the point of views epidemiological (Galvão, 2014; WHO, 2015). Schofield and Galvão (2009) grouped these triatomines in complexes and specifics subcomplexes mainly based on morphological characters and geographic disposition. The flavida complex consists of the species Nesotriatoma bruneri Usinger, 1944, N. flavida (Neiva, 1911) and N. obscura Maldonado and Farr, 1962 [although recently it has been suggested that $N$. bruneri and $N$. flavida should be again synonymized (Alevi et al., 2016)].

Recently, Justi et al. (2014, 2016) claim that although the complexes and subcomplexes show no taxonomic validity they must be monophyletic groups. Thus, the authors presented a phylogenetic reconstruction for the species groupings proposed by Schofield and Galvão (2009) and observed that many groups are not monophyletic (brasiliensis, maculata, matogrossensis, flavida and sordida subcomplexes). The flavida complex although it has formed a monophyletic group, curiously was presented as evolutionarily related to Panstrongylus genus, as has been observed by other authors (Hypsa et al., 2002).

Therefore, we will group all information related to the number and morphology of the chromosomes of
Nesotriatoma spp. and Panstrongylus spp. with intuited of analyze the chromosomal relationship of these triatomines.

All species of Panstrongylus genus (except P. megistus and P. lutzi) and Nesotriatoma genus presents the karyotype $2 \mathrm{n}=23\left(20 \mathrm{~A}+\mathrm{X}_{1} \mathrm{X}_{2} \mathrm{Y}\right)$ (Table 1). Furthermore, all species of both genera (except $P$. lutzi) showed the same system of sex determination, as well as the same chromosomal characteristics (Table 1).

Recently, by means of dated phylogeny was supported that the ancestral of Nesotriatoma arrived in the Antillean islands approximately 14.8-18.8 millions of years (associated with rodent subfamily Capromyinae) (Justi et al., 2016) and by phylogenetic analysis we can see that Nesotriatoma and Panstrongylus share an ancestor comum (Justi et al., 2014, 2016). Was suggested that the ancestor of these vectors presented karyotype $2 n=23$ and that during the divergence and karyotype evolution of species occurred one event punctual of simploidy in the autosome of $P$. megistus and agmatoploidy in the $\mathrm{X}$ sex chromosome of P. lutzi (Alevi and Azeredo-Oliveira, 2018).

Thus, by karyosystematic we confirm the phylogenetic relationship between flavida complex and Panstrongylus genus. We suggest that experimental hybrid crosses are to be conducted for analysis of possible prezygotic and postzygotic barriers installed in the Panstrongylus and Nesotriatoma genus. 
Table 1. Chromosomal characteristics of the species of flavida complex and Panstrongylus genus.

$\begin{array}{lllll} & \\ & & & & \\ & & & \end{array}$

$\mathrm{X}$ : X sex chromosome; Y: Y sex chromosome.

\section{Acknowledgements}

The study was supported by Fundação de Apoio à Pesquisa e Extensão de São José do Rio Preto (Process number 60/2015-FAPERP, Brazil) and the Conselho Nacional de Desenvolvimento Científico e Tecnológico (CNPq, Brazil).

\section{References}

ALEVI, K.C.C. and AZEREDO-OLIVEIRA, M.T.V., 2018. Karyotype evolution of Chagas disease vectors. American Journal of Tropical Medicine and Hygiene. In press.

ALEVI, K.C.C., IMPERADOR, C.H.L., FONSECA, E.O.L., SANTOS, C.G.S., AZEREDO-OLIVEIRA, M.T.V., ROSA, J.A. and OLIVEIRA, J., 2017. Karyosystematic and karyotype evolution of Panstrongylus lutzi (Neiva \& Pinto, 1923) (Hemiptera, Triatominae). Brazilian Journal of Biology $=$ Revista Brasileira de Biologia. In press. PMID: 28562784. http://dx.doi. org/10.1590/1519-6984.166442.

ALEVI, K.C.C., REIS, Y.V., GUERRA, A.L., IMPERADOR, C.H.L., BANHO, C.A., MOREIRA, F.F.F. and AZEREDOOLIVEIRA, M.T.V., 2016. Would Nesotriatoma bruneri Usinger, 1944 be a valid species? Zootaxa, vol. 4103, no. 4, pp. 396-400. PMid:27394745. http://dx.doi.org/10.11646/zootaxa.4103.4.8.
DUJARDIN, J.P., SCHOFIELD, C.J. and PANZERA, F. 2002. Los vectores de la enfermedad de Chagas. Brussels: Académie Royale des Science d'Outre Mer. 189 p.

GALVÃO, C. (2014). Vetores da doença de chagas no Brasil. Curitiba: Sociedade Brasileira de Zoologia. 289 p.

HYPSA, V., TIETZ, D., ZRZAVY, J., REGO, R.O., GALVAO, C. and JURBERG, J., 2002. Phylogeny and biogeography of Triatominae (Hemiptera, Reduviidae): molecular evidence of a New World origin of the asiatic clade. Molecular Phylogenetics and Evolution, vol. 23, no. 3, pp. 447-457. PMid:12099798. http:// dx.doi.org/10.1016/S1055-7903(02)00023-4.

JUSTI, S.A., GALVÃO, C. and SCHRAGO, C.G., 2016. Geological changes of the Americas and their Influence on the diversification of the Neotropical Kissing Bugs (Hemiptera: Reduviidae: Triatominae). PLoS Neglected Tropical Diseases, vol. 10, no. 4, pp. e0004527. PMid:27058599. http://dx.doi. org/10.1371/journal.pntd.0004527.

JUSTI, S.A., RUSSO, C.A.M., MALLET, J.R.S., OBARA, M.T. and GALVÃO, C., 2014. Molecular phylogeny of Triatomini (Hemiptera: Reduviidae: Triatominae). Parasites \& Vectors, vol. 7, no. 1, pp. 149. PMid:24685273. http://dx.doi.org/10.1186/17563305-7-149.

MENDONÇA, V.J., ALEVI, K.C.C., PINOTTI, H., GURGELGONGALVES, R., PITA, S., GUERRA, A.L., PANZERA, F., ARAÚJO, R.F., AZEREDO-OLIVEIRA, M.T.V. and ROSA, J.A. 2016. Revalidation of Triatoma bahiensis Sherlock \& Serafim, 
1967 (Hemiptera: Reduviidae) and phylogeny of the T. brasiliensis species complex. Zootaxa, vol. 4107, no. 2, pp. 239-254. PMID: 27394816. http://dx.doi.org/10.11646/zootaxa.4107.2.6.

PÉREZ, R., HERNÁNDEZ, M., CARACCIO, M., ROSE, V., VALENTE, A., VALENTE, V., MORENO, J., ANGULO, V., SANDOVAL, M., ROLDÁN, J., VARGAS, F., WOLFF, M. and PANZERA, F., 2002. Chromosomal evolution trends of the genus Panstrongylus (Hemiptera, Reduviidae), vectors of Chagas Disease. Infection, Genetics and Evolution, vol. 2, no. 1, pp. 47-56. PMid:12798000. http://dx.doi.org/10.1016/S15671348(02)00063-1.

ROSA, J.A., JUSTINO, H.H.G., NASCIMENTO, J.D., MENDONÇA, V.J., ROCHA, C.S., CARVALHO, D.B., FALCONE, R., AZEREDOOLIVEIRA, M.T.V., ALEVI, K.C.C. and OLIVEIRA, J., 2017. A new species of Rhodnius from Brazil (Hemiptera, Reduviidae, Triatominae). ZooKeys, vol. 675, pp. 1-25.

SANTOS, S.M., POMPOLO, S.G., GONÇALVES, T.C.M., FREITAS, S.P.C., RANGEL, S.P. and SANTOS-MALLET, J.R., 2016. New sex-determination system in the genus Panstrongylus (Hemiptera, Reduviidae) revealed by chromosomal analysis of
Panstrongylus lutzi. Parasites \& Vectors, vol. 9, no. 1, pp. 295. PMid:27209318. http://dx.doi.org/10.1186/s13071-016-1574-6.

SCHOFIELD, C.J. and GALVÃO, C., 2009. Classification, evolution, and species groups within the Triatominae. Acta Tropica, vol. 110, no. 2-3, pp. 88-100. PMid:19385053. http:// dx.doi.org/10.1016/j.actatropica.2009.01.010.

SCHREIBER, G. and PELLEGRINO, J., 1950. Eteropicnosi di autosomi come possible meccanismo di speciazione (Ricerche citologiche su alcuni Emitteri neotropici). Sciencia Genetica, vol. 3, pp. 215-226.

SOUZA, E.S., ATZINGER, N.C.B.V., FURTADO, M.B., OLIVEIRA, J., DAMIELI, J.N., VENDRAMINI, D.P., GARDIM, S. and ROSA, J.A., 2016. Description of Rhodnius marabaensis sp. N. (Hemiptera: Reduviidae: Triatominae) from Pará State, Brazil. ZooKeys, vol. 621, no. 621, pp. 45-62. PMid:27833419.

WORLD HEALTH ORGANIZATION - WHO, 2015. Chagas Disease (American Trypanosomiasis). Weekly Epidemiological Record, vol. 90, pp. 33-44. PMid:25671846. 